from New-Zealand seas, 48 from either New-Zealand or Australian waters, and 28 have been found fossil in Australia. Judging from these alone, it would seem that some authors have assigned too remote an age to the deposits. The new forms described were:-

Membranipora accultata

Monoporella capensis, var. dentata. waipukurensis.

Micropora variperforata.

Mueron+lla tricuspis, var. waipukurensis.

$\longrightarrow$ - $\longrightarrow$ var. minima.

- firmata.
Porina grandipora.

Lepralia semiluna, var. simplex.

- bistata

Schizoporella cinctipora, var. personata.

- tuberosa, var. angustata.

Cellepora decepta.

$\longrightarrow$ sp.

\title{
COREESPONDENTEF \\ ON THE OCCURRENCE OF PHOSPHATIC NODULES IN THE LOWER GREENSAND, EAST OF SANDOWN.
}

SIR,-When working near Sandown, in company with Mr. H. Keeping, we observed several beds of phosphatic nodules in the Lower Greensand; these do not appear to have been previously noticed, no mention being made of them in the Survey or other memoirs on the district. Mr. Bristow describes some " concretionary masses or bodies" which occur in Fitton's bed No. xvi. at Rocken End, near Black Gang: these may represent some of the nodule beds at Sandown.

The phosphates are of a light brown colour, and occur at four horizons. The three lowermost are very distinct, and come between 160 and 200 fect from the top of the Lower Greensand, whilst the fourth is some distance higher up. The second band from the bottom is about seven inches in thickness, and from it the following fossils were obtained:Ammonites biplex, Sow. A. cordatus, Sow. Pleurotomaria sp. Cardium striatulum? Lucina sp. Myacites sp. Cytherea rugosa? Arca contracta, Phill. They are all much rounded, and difficult to determine. In this bed there are also fragments of various rocks, such as quartzite, lydian stone, ete., the first of which greatly resembles those in the Budleigh Salterton pebble bed. The nodules in the upper band are much smaller, and are associated with a great many quartz pebbles.

The phosphates and fossils of the lower beds are very similar to those of Brickhill and Potton in Bedfordshire, Wicken in Cambridgeshire, and Tealby in Lincolnshire. The second bed noticed above is sufficiently thick to be worked for commercial purposes, but the strata dip at such a high angle, that but little of the phosphates could be profitably obtained.

The Geological Survey is now engaged in the district, and the exact horizons at which the nodules occur will no doubt be given in their sections.

H. Woods.

Woodwardian Museum, Cambridge.

\section{THE PEA GRIT OF LECKHAMPTON HILL.}

Srr,--The letter of my friend, Mr. F. Wethered, in the last number of the Magazine, requires some notice from me. Mr. Wethered takes exception to a remark in my paper on the basement-beds of the Inferior Oolite, that the beds between the Pea Grit proper and the 
Cephalopoda-bed have been included by the late Dr. Wright and others in their published works in the term "Pea Grit," and he refers me to the paper by Dr. Wright on the so-called sands of the Inferior Oolite" as showing that I am in error. I have referred to the paper cited, and find that in the section (Fig. 1) only one bed is shown as including the Pea Grit and the underlying beds, although in the explanation at foot it is called "Pea Grit and ferruginous oolite," and marked A B C; but the description in the following page is headed "Pea Grit (Inferior Oolite)," and under this heading the beds $\mathrm{A}$ B and $\mathrm{C}$ are described: the description of $\mathrm{A}$ and $\mathbf{B}$ appears, however, to be substantially the same.

In Dr. Wright's latest work " Monograph on the Lias Ammonites" the section of Leckhampton Hill is repeated (fig. 11, page 151); and on reference to the description (p. 152), I find the heading is "Pea Grit (Zone of Harpoceras Murchisonia, Inferior Oolite)," the subdivision being the same as before, and the description being wholly under this beading.

I think the meaning is clear, namely, that it was intended that the term "Pea Grit" should apply to all the beds, although, for the purpose of giving a more accurate description, a subdivision of them was convenient.

Mr. Wethered refers me to Dr. Wright's section of Cleeve Hill, but the extract is incorrectly given, doubtless an error in printing.

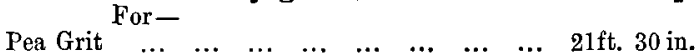

$$
\begin{aligned}
& \begin{array}{llllllll}
\text { Coarse ferruginous oolite } & \ldots & \ldots & \ldots & \ldots & \ldots & \ldots & 22 \mathrm{ft} . \\
5
\end{array} \\
& \text { Read- }
\end{aligned}
$$

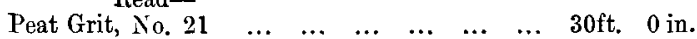

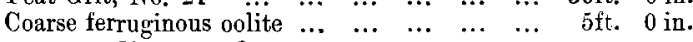

The correct reading confirms my statement, except as regards the lower $5 \mathrm{ft}$.

The section of Cleeve Hill is also repeated in the monograph on the Lias Ammonites (fig. 12, p. 155), and in the description (p. 161) the beds are called "Pea Grit," and the three subdivisions are described in much the same language as is used in the description of the beds at Leckhampton.

EDwis Witchell.

\section{CORRECTION OF MIOCENE INSECTIVORA.}

Sir,-With your permission I will avail myself of the Geologrcar Magazine to correct an error into which I have been led by the writings of others in part $i$. of the "Catalogue of Fossil Mammalia in the British Museum" (1875).

On page 19 of that volume I followed Dr. O. Fraas' in identifying the Auvergne Plesiosorex soricinoides (Erikaceus soricinoides, of Blainville) with Parasorex socialis, Meyer, of Steinheim. Having recently, however, had cause to consider further the affinities of the Miocene Insectivora, I have been led from an examination of the figures given by Fraas and De Blainville to the conclusion that the identifications made by the former writer are totally erroneous. The Steinheim Parasorex socialis is, as Fraas states, closely allied to 1 “Fauna von Steinheim," p. 4 (1870). 